\title{
WZORZEC GATUNKOWY SKARGI W NAUCZANIU JEZYKA POLSKIEGO JAKO OBCEGO
}

\begin{abstract}
Slowa kluczowe: glottodydaktyka polonistyczna, kompetencja genologiczna, wzorzec gatunkowy skargi

Streszczenie. Celem artykułu jest zaprezentowanie wyników analizy sposobów realizacji polskiego wzorca gatunkowego skargi przez słowiańskojęzycznych studentów uczących się języka polskiego w Centrum Języka i Kultury Polskiej dla Polonii i Cudzoziemców UMCS w Lublinie. Badanie zostało przeprowadzone dwukrotnie - na początku i na końcu roku akademickiego - dlatego wyniki analizy pozwalają na zaobserwowanie poziomu wzrostu kompetencji komunikacyjnych uczących się oraz wskazanie elementów, na które należy zwrócić szczególną uwagę w procesie nauczania. Artykuł podkreśla także potrzebę zwrócenia większej uwagi na kształcenie kompetencji genologicznej oraz wykorzystanie w praktyce glottodydaktycznej osiągnięć genologii. Zawiera również charakterystykę polskiego wzorca gatunkowego skargi.
\end{abstract}

Duża grupa uczących się języka polskiego to pochodzący zza naszej wschodniej granicy imigranci, którzy planują podjęcie nauki i/lub pracy w Polsce. Dłuższy pobyt w obcym kraju wiąże się dla nich nie tylko z koniecznością wcielania się w rolę cudzoziemca-petenta (związaną m.in. z legalizacją pobytu czy uzyskaniem pozwolenia na pracę), ale także w role oraz sytuacje komunikacyjne właściwe polskim obywatelom. Choć duża część potrzeb komunikacyjnych jest zaspokajana dzięki znajomości języka ogólnego, to sytuacje wyjątkowo ważne wymagają często znajomości języka specjalistycznego, szczególnie w jego formie pisemnej. Sprawność pisania jest spośród wszystkich czterech sprawności najtrudniejsza do opanowania zarówno w języku ojczystym, jak i obcym. Wyjątkowo trudna jest sprawność pisania w zakresie komunikacji instytucjonalnej, która wymaga wysokiego poziomu kompetencji komunikacyjnych, w tym szczególnie kompetencji genologicznej.

*kamila.kwiatkowska@umcs.pl, Uniwersytet Marii Curie-Skłodowskiej w Lublinie, Centrum Języka i Kultury Polskiej dla Polonii i Cudzoziemców, ul Weteranów 18, 20-400 Lublin. 


\section{KOMPETENCJA GENOLOGICZNA W GLOTTODYDAKTYCE}

Choć kompetencja genologiczna jest istotnym elementem kompetencji komunikacyjnej, to jak zauważają Anna Dunin-Dudkowska (2018) i Beata Grochala (2019) na gruncie glottodydaktyki ciągle jeszcze zbyt mało miejsca poświęca się problematyce jej kształcenia. Termin kompetencja genologiczna ${ }^{1}$ pojawia się w literaturze poświęconej gatunkom tekstów i oznacza „znajomość i umiejętność konstruowania gatunków" (Grochala 2019, s. 223). Maria Wojtak wyjaśnia, że kompetencja ta obejmuje: „wiedzę o gatunkach, znajomość wzorców konkretnych gatunków, umiejętność stosownej dyskursywnej realizacji wzorców" (Wojtak 2019, s. 178).

Stanisław Gajda definiuje gatunek wypowiedzi jako „kulturowo i historycznie ukształtowany oraz ujęty w społeczne konwencje sposób językowego komunikowania się; wzorzec organizacji tekstu" (Gajda 2001, s. 255). Gatunki są więc ściśle powiązane z przestrzenią kulturowo-językową, w której funkcjonują. Ponadto, jak stwierdził Michaił Bachtin (1986), wszystkie nasze wypowiedzi mają charakter gatunkowy, dlatego też umieć mówić znaczy tyle, „,co umieć tworzyć gatunkowo ukształtowane konkretne teksty" (Gajda 2001, s. 256). W takim kontekście kształcenie kompetencji genologicznej nabiera w nauczaniu języków obcych szczególnego znaczenia. Skoro komunikujemy się przy użyciu gatunków, to umiejętność ich konstruowania powinna być rozwijana w sposób celowy, zorganizowany i systematyczny już od najwcześniejszych etapów nauki. Należy kształcić kompetencję genologiczną zarówno w zakresie języka ogólnego, jak i specjalistycznego odpowiednio do potrzeb i poziomu zaawansowania uczących się.

Wśród wielu rodzajów kompetencji wymienianych w Europejskim systemie opisu ksztatcenia językowego (ESOKJ) nie pojawia się pojęcie kompetencji genologicznej, przy czym jak zauważa Grochala, częściowo pokrywa się ono z kompetencją dyskursywną². Kompetencja dyskursywna obejmuje, m.in. formalny i organizacyjny układ tekstów pisanych, umiejętność układania zdań w wypowiedzi spójne pod względem strukturalnym i semantycznym, zachowanie kohezji i koherencji czy przestrzeganie maksym konwersacyjnych (ESOKJ 2003, s. 110). Zdaniem Grochali jest to podejście tekstologiczne - ważne i cenne jak podkreśla badaczka - jednak niewystarczające i wymagające uzupełnienia o element genologiczny (Grochala 2019, s. 223).

${ }^{1} \mathrm{Na}$ określenie kompetencji genologicznej stosowane są także terminy: świadomość gatunkowa, świadomość genologiczna, kompetencja generyczna, kompetencja gatunkowa (Grochala 2019, s. 222-223).

${ }^{2}$ Kompetencja dyskurywna stanowi element kompetencji pragmatycznej, definiowanej jako „znajomość zasad, według których przekaz językowy jest: organizowany, budowany i układany (kompetencja dyskursywna); używany w celu wypełnienia określonej funkcji komunikacyjnej (kompetencja funkcjonalna); porządkowany według schematów interakcyjnych i transakcyjnych (znajomość schematów)" (ESOKJ 2003, s. 109). 
Na potrzebę sięgnięcia do dorobku genologii w praktyce glottodydaktycznej zwraca uwagę również Dunin-Dudkowska. W jednym ze swoich artykułów badaczka pisze: „Nauczanie języka polskiego jako obcego i kultury polskiej nie może ignorować zdobyczy genologii, która dostrzega decydującą rolę kultury w kształtowaniu gatunków. Ucząc wypowiedzi gatunkowych, zarówno ustnych, jak i pisemnych, tak czynnie jak i biernie, powinniśmy czerpać z instrumentarium genologów, wykorzystując pojęcie wzorca gatunkowego ${ }^{3}$ i stosując zasady metodyki nauczania jpjo" (Dunin-Dudkowska 2018, s. 120).

Szczególnie cenne dla praktyki glottodydaktycznej są wyniki analiz komparatystycznych, które pozwalają na wskazanie różnic pomiędzy analogicznymi gatunkami w różnych kulturach, a tym samym wskazanie cudzoziemcom miejsc grożących wystąpieniem transferu negatywnego (Dunin-Dudkowska 2018, s. 117). Implikacje praktyczne mają także badania poświęcone analizie konkretnych realizacji wzorców gatunkowych ${ }^{4}$, gdyż pozwalają one nie tylko na diagnozę kompetencji komunikacyjnych piszących, ale również na wyciągnięcie wniosków, służących usprawnieniu procesu kształcenia.

\section{SKARGA NA LEKTORACIE JEZZYKA POLSKIEGO}

Choć skarga jest gatunkiem tekstu, z którym nie stykamy się na co dzień, to umiejętność jej pisania może niekiedy okazać się bardzo cenna. Pozwala nam ona bronić swoich praw i uważana jest za ,jedną z form udziału obywateli w rządzeniu i wpływania na działalność organów państwowych" (Wyrwas 2002, s. 77). Wydaje się, że przeciętny człowiek, a zwłaszcza młody student, rzadko sięga po to specyficzne „narzędzie obrony”, gdyż albo nie zdaje sobie sprawy, że może napisać skargę, albo nie wie, jak to zrobić. W przypadku cudzoziemców pochodzących ze Wschodu poziom tej świadomości oraz wiary w możliwość obrony swoich praw jest jeszcze niższy.

Programy nauczania języka polskiego jako obcego. Poziomy A1-C2 (2016) wymieniają gatunki tekstów urzędowych dopiero na poziomie B2. Wśród zalecanych form znajdują się, m.in.: życiorys, podanie, list motywacyjny czy list urzędowy. Skarga pojawia się natomiast dopiero na poziomie C1. Na egzaminie certyfikatowym teksty urzędowe również wymagane są dopiero na poziomie B2, przy czym skarga w ogóle nie pojawia się w regulującym egzaminy dokumencie (Rozporządzenie MNiSW 2016).

${ }^{3}$ W swoich pracach Dunin-Dudkowska $(2016,2018$ i 2019) zwraca szczególną uwagę na użyteczność w nauczaniu języków obcych koncepcji opisu wzorca gatunkowego Marii Wojtak.

${ }^{4}$ Wzorzec gatunkowy rozumiem jako idealny model organizacji tekstu. 
Cudzoziemcy starający się o polskie obywatelstwo muszą wykazać się znajomością języka polskiego minimum na poziomie B1. Biorąc pod uwagę fakt, że ustawodawca zakładał, iż poziom ten jest wystarczający do pełnienia roli obywatela, pracownika czy petenta, można śmiało stwierdzić, że gatunki tekstów urzędowych powinny być wprowadzane właśnie na tym poziomie. Potwierdzeniem słuszności tej teorii jest katalog tekstów użytkowych zaproponowany przez Samantę Busiło. W zestawieniu opracowanym na podstawie analizy potrzeb imigrantów mieszkających w Polsce Busiło wymienia skargę wśród gatunków, które powinny być wprowadzane na poziomie B1/B2 (Busiło 2017, s. 56).

Wzorzec gatunkowy skargi nie pojawia się zbyt często w podręcznikach do nauczania języka polskiego jako obcego. Na szczególną uwagę zasługuje tu więc podręcznik Andrzeja Ruszera Oswoić tekst. Podręcznik kompozycji i redakcji tekstów użytkowych dla poziomów B2 $i$ Cl, w którym jedna z lekcji poświęcona jest problematyce pisania skargi, reklamacji oraz zgłaszania wypadku (Ruszer 2010, s. 35-36).

\section{WZORZEC GATUNKOWY SKARGI}

Katarzyna Wyrwas, autorka monografii Skarga jako gatunek mowy (2002), skargę w sensie administracyjnym ${ }^{5}$ definiuje na podstawie kodeksu postępowania administracyjnego (Ustawa z dnia 14 czerwca 1960 r.) jako „prawną możliwość zaskarżenia w określonej formie przez obywatela lub organ organizacji społecznej każdej nieprawidłowości w działaniu organu państwowego, państwowej jednostki organizacyjnej, organu organizacji społecznej, gdy wykonuje on funkcje administracji państwowej względnie wykonuje zadania państwa, a także uspołecznionej jednostki organizacyjnej prowadzącej działalność przemysłową, handlową czy usługową, o ile przez to działanie zostaje naruszony interes własny skarżącego, interes innej osoby lub interes społeczny" (Wyrwas 2002, s. 76-77).

Skarga jako pismo administracyjne jest ,jedną z form porozumiewania się obywatela z instytucją" (Wyrwas 2000, s. 126-127). Zakres sytuacji, w których może być składana, jest bardzo szeroki. Jej intencją komunikacyjną jest powiadomienie adresata o wydarzeniach, które nadawca uważa za krzywdzące i w związku z tym oczekuje od odbiorcy interwencji, wyciągnięcia konsekwencji i ukarania ewentualnego sprawcy (Wyrwas 2002, s. 95). Zgodnie z ustawą można ją złożyć „w interesie publicznym, własnym lub innej osoby za jej zgodą" (Ustawa z dnia 14 czerwca 1960 r., art. 221, §3).

${ }^{5}$ Wyrwas wyjaśnia, że skarga jako pismo administracyjne jest gatunkiem wtórnym wobec skargi mówionej, realizującej się w dialogu potocznym, rozumianej jako „wszelkie werbalne reakcje na poczucie krzywdy czy złe samopoczucie" (2002, s. 10). 
Polski wzorzec gatunkowy skargi częściowo determinowany jest przez kodeks postępowania administracyjnego, a częściowo przez konwencje przyjęte w korespondencji oficjalnej (Wyrwas 2002, s. 82). Kodeks nie zawiera szczegółowego opisu wzorca, w artykule 222 czytamy, że: „O tym, czy pismo jest skargą (...), decyduje treść pisma, a nie jego forma zewnętrzna”. Jak zauważa Wyrwas niezbędne jest jedynie podanie imienia, nazwiska i adresu osoby składającej skargę (Wyrwas 2002, s. 80).

O wiele bardziej rygorystyczne są opracowania poprawnościowe zawierające szczegółowy wykaz elementów skargi, ich graficzne rozmieszczenie oraz wymagania dotyczące językowej i merytorycznej strony pisma (por. m.in.: Zaśko-Zielińska i in. 2006, s. 764-765). Jak bowiem podkreśla Wyrwas, ,językowy kształt tekstu oficjalnego jest elementem komunikacji równie istotnym jak jego treść". Dlatego też oficjalna skarga do instytucji powinna się wpisywać „,W pewien szablon odpowiadający komunikacji typowej dla sfery urzędowej” (Wyrwas 2000, s. 127).

Poniżej znajduje się wykorzystany w przeprowadzonych analizach schemat wzorca gatunkowego skargi, opracowany przez Wyrwas (2000, s. 127-128 i 2002, s. 84-85), jednak poddany pewnym modyfikacjom na wzór schematu podania ustalonego przez Ewę Malinowską (2001, s. 115-122) ${ }^{6}$.

1. Rama tekstowa

1.1. Podmiot skargi: imię, nazwisko, adres, nr telefonu, adres mailowy

1.2. Adresat: imię, nazwisko, adres

1.3. Miejscowość i data

1.4. Tytuł: Skarga

1.5. Podpis

1.6. Zapewnienie o szacunku

2. Treść skargi

2.1. Formuła początkowa

2.1.1. Zwrot grzecznościowy

2.1.2. Powołanie się na normy prawne

2.1.3. Informacje o typie działania językowego

2.2. Zasadnicza treść pisma

2.2.1. Przedmiot skargi:

a) Obiekt skargi (osoba, instytucja)

b) Przewinienie

c) Okoliczności zdarzenia (opis, narracja)

2.2.2. Projektowanie stanu pożądanego / ocena / komentarz

2.2.3. Określenie stanu emocjonalnego

${ }^{6} \mathrm{Na}$ wzór schematu podania zaproponowanego przez Malinowską zrezygnowałam z podziału na inicjalną i finalną ramę tekstową, a niektóre elementy ramy tekstowej (np. inicjalny zwrot grzecznościowy i apel) zaliczyłam do treści pisma, w obrębie której wyróżniłam trzy części: formułę początkową, zasadniczą treść skargi oraz formułę finalną. 
2.3. Formuła końcowa (finalna)

\subsubsection{Petitum}

2.3.2. Apel (prośba o rozpatrzenie, prośba o odpowiedź)

2.3.3. Podziękowania

3. Dodatkowe informacje:

3.1. Informacja o świadkach zdarzeń

3.2. Informacja o załącznikach

3.3. Informacja o przekazaniu pisma

\section{ANALIZA WYNIKÓW BADAŃ}

W dalszej części przedstawione zostaną wyniki analizy wybranych aspektów realizacji wzorca gatunkowego skargi. Podstawę materiałową stanowi 110 tekstów napisanych przez studentów tzw. „roku zerowego”, uczących się w Centrum Języka i Kultury Polskiej dla Polonii i Cudzoziemców UMCS w Lublinie. W grupie badawczej znalazła się polska młodzież z Ukrainy, Białorusi i Kazachstanu. Pomimo polskiego pochodzenia dla większości z tych osób język polski jest językiem obcym, poznawanym głównie w ramach lekcji prowadzonych w szkołach, szkołach sobotnio-niedzielnych oraz organizacjach polonijnych.

Studenci zostali poproszeni o napisanie skargi na sprzedawcę, przez którego zostali źle potraktowani (wybór tematu podyktowany był dużym prawdopodobieństwem wystąpienia takiego zdarzenia). Badanie zostało przeprowadzone dwukrotnie, na początku i na końcu roku akademickiego (w pierwszym etapie udział wzięły 62 osoby, w drugim 48 osób). Przeprowadzone analizy dają więc obraz znajomości wzorca i umiejętności jego realizacji tuż po przyjeździe do Polski oraz po roku nauki.

\subsection{RAMA TEKSTOWA}

Rama tekstowa skargi ma charakter uniwersalny - podobny, a często wręcz identyczny schemat pojawia się także w innych pismach użytkowych, np. w podaniu, reklamacji, liście urzędowym, liście motywacyjnym czy życiorysie. Jest to więc element, który należy wprowadzać od najwcześniejszych etapów nauki, gdyż raz przyswojony może być wykorzystywany w różnych sytuacjach.

Rama tekstowa nadaje pismu odpowiednią formę, jej obecność wpływa na potencjał illokucyjny tekstu, a często także na jego ważność, jak w przypadku podpisu, którego brak może spowodować, że pismo nie zostanie rozpatrzone. 
W wersji maksymalnej występuje 6 elementów ramy tekstowej: (1) informacje o podmiocie skargi, (2) informacje o adresacie, (3) miejsce i data pisania tekstu, (4) tytuł, (5) podpis oraz (6) zapewnienie o szacunku.

W pierwszym etapie badania największa grupa studentów $(27,42 \%)$ nie uwzględniła żadnego elementu ramy tekstowej, a 24,20\% zamieściło tylko $1 \mathrm{z}$ nich - był to zazwyczaj podpis lub tytuł. Jednocześnie także $21,85 \%$ badanych uwzględniło aż 5 elementów. W drugim etapie badania nastąpił znaczny wzrost świadomości budowy ramy tekstowej - wprawdzie tylko $18,75 \%$ pamiętało o wszystkich jej częściach, ale aż $62,50 \%$ pominęło tylko jedną z nich (najczęściej był to tytuł, który przez niektórych badaczy uznawany jest za element fakultatywny ${ }^{7}$ ). Szczegółowe informacje na temat liczby osób uwzgledniających określoną liczbę elementów ramy tekstowej w kolejnych etapach badania zawiera poniższa tabela.

Tabela 1. Liczba osób uwzględniajacych określona liczbę elementów ramy tekstowej $w d$ wóch etapach badania

\begin{tabular}{|c|c|c|c|c|c|c|c|c|}
\hline \multicolumn{2}{|c|}{$\begin{array}{c}\text { Liczba elementów } \\
\text { ramy tekstowej }\end{array}$} & 6 & 5 & 4 & 3 & 2 & 1 & 0 \\
\hline $\begin{array}{c}\text { Liczba } \\
\text { osób } \\
(\%)\end{array}$ & Etap I & 4,83 & 21,85 & 11,29 & 10,41 & - & 24,20 & 27,42 \\
\cline { 2 - 8 } & Etap II & 18,75 & 62,50 & 4,83 & 6,25 & 5,59 & 2,08 & - \\
\hline
\end{tabular}

Źródło: opracowanie własne

Na podstawie powyższych danych można stwierdzić, że po roku nauki nastąpił znaczny wzrost świadomości budowy ramy tekstowej, zarówno skargi, jak i innych pism użytkowych, w których struktura ta się powtarza ${ }^{8}$. Poziom ten uznać jednak należy za nie do końca zadowalający, gdyż w drugim etapie aż 18,75\% badanych ciągle jeszcze pomijało od 2 do 5 elementów. Świadczy to nie tylko o słabym poziomie znajomości polskiego wzorca gatunkowego skargi, czy też szerzej ramy tekstowej pism użytkowych, ale także o brakach w zakresie kompetencji genologicznej w języku ojczystym. W krajach, z których pochodzą badani studenci, funkcjonują bowiem wzorce zarówno skargi, jak i innych pism użytkowych". $\mathrm{W}$ ich strukturze występują te same elementy ramy tekstowej, a różnice dotyczą głównie ich rozmieszczenia. Dlatego też w badanym materiale pojawiały się teksty, w których np. dane nadawcy zamieszczane były z prawej strony pod danymi adresata, a data i miejsce w lewym dolnym rogu pisma. Błędy w graficznym rozmieszczeniu elementów ramy tekstowej są często wynikiem interferencji z języka rodzimego. Brak wymaganych elementów jest natomiast efektem braku świadomości jakiegokolwiek wzorca.

\footnotetext{
${ }^{7}$ Uważa tak m.in. wspominana tu już Wyrwas (2002).

${ }^{8}$ Więcej na temat ramy tekstowej w tekstach użytkowych pisanych przez polską młodzież ze Wschodu zob. m.in. Kwiatkowska (2011 i 2012).

${ }^{9}$ Por. wzory pism użytkowych m.in. w Makarewicz (2007).
} 
Z przeprowadzonych analiz wynika, że elementem, na który należy zwracać szczególną uwagę w nauczaniu języka polskiego jako obcego, jest sposób zapisu adresu. Znajomość poprawnego wzorca jest szczególnie istotna w przypadku osób mieszkających w Polsce, gdyż z danymi adresowymi stykają się one w różnych sytuacjach życiowych. W badanym materiale w pierwszym etapie dane adresowe podało $30,64 \%$ studentów, a w drugim $83,33 \%$. Co ciekawe, adresy nadawców podawane w pierwszym etapie badania $\mathrm{w} 77,77 \%$ były zapisane poprawnie, w drugim etapie już tylko w 32,50\%. Wzrosła więc świadomość potrzeby zamieszczania danych adresowych w obrębie ramy tekstowej, lecz znajomość poprawnego zapisu nie została jeszcze wystarczająco ugruntowana. Badani studenci często pomijali niektóre elementy adresu, a jeśli nawet podawali wszystkie, to zapisywali je w dowolnym porządku. Najczęściej popełniane błędy dotyczyły: braku kodu pocztowego, zamieszczania kodu i nazwy miasta w oddzielnych wierszach, oddzielania poszczególnych elementów przecinkami, a nawet umieszczania imienia i nazwiska nadawcy pod adresem. Poniżej znajdują się przykłady błędnego zapisu danych adresowych.

(1) Katarzyna Kuchalska

Lublin, ul. Langiewicza, 11

20-601

sister.16@mail.ru

tel. 809-580-643
(2) Izabela Kucewicz

Lublin ul. Czwartaków 15

DS ,,Ikar” pokuj 316

tel.: + 37320866542

e-mail: izab.kuc@gmail.com
(3) 20-601 Lublin

ul. Lipowa 6, ap.67

Krystyna Sańko

\subsection{TREŚĆ SKARGI}

Treść skargi składa się z 3 części: formuły początkowej, zasadniczej treści pisma i formuły końcowej. Podobnie jak w innych pismach użytkowych, również w skardze występują stałe formuły rozpoczynające i kończące zasadniczą treść pisma.

Formula początkowa może być złożona z następujących elementów: zwrot grzecznościowy do adresata (Szanowny Panie Dyrektorze!), powołanie się na normy prawne (Na podstawie art. 230 k.p.a.) oraz informacje o typie działania językowego (wnoszę skargę na pracownika Państwa sklepu, Pana Jana Nowaka). Porównanie materiałów zebranych na początku i na końcu roku akademickiego wskazuje na znaczne różnice jakościowe stosowanych formuł początkowych. Choć duża część studentów na pierwszym etapie badania miała świadomość ich istnienia oraz potrzeby stosowania, to ich niedostateczna znajomość oraz niski poziom kompetencji językowych powodowały występowanie licznych błędów. Oto kilka przykładów z pierwszego etapu badania ${ }^{10}$ :

\footnotetext{
${ }^{10}$ We wszystkich przykładach zachowana została oryginalna pisownia.
} 
- Chciałbym panu podać skargę na jednego z pracowników waszego sklepu.

- Chciałabym oskarżyć jedną pracowniczkę waszego sklepu.

- Chcę poskarzyć się na pańskiego sprzedawcę.

- Szanowny Panie, piszę skargę z powodu nieprzyjemnego przyjęcia mojej osoby w sklepie.

Różnego rodzaju usterki językowe pojawiały się także na drugim etapie badania, jednak dzięki lepszej znajomości stałych formuł oraz wyższemu poziomowi kompetencji językowych ich liczba była znacznie mniejsza, a stosowane zwroty były bardziej rozbudowane. Oto kilka przykładów:

- Szanowny Panie Dyrektorze, chciałbym powiadomić Pana o niekulturalnym i nieprzyzwoitym zachowaniu jednego z waszych pracowników.

- Zwracam się do administracji sklepu RTV „ABC” z prośbą o rozpatrzenie mojej skargi.

- Chciałabym złożyć skargę z powodu niekompetencji pracowników państwa sklepa.

W formule początkowej skargi nadawca może powołać się na normy prawne mające zastosowanie w opisywanej przez niego sprawie. W analizowanym materiale odwołania takie pojawiły się w $10,41 \%$ tekstów pochodzących tylko $\mathrm{z}$ drugiego etapu badania (np.: Na podstawie art. 227 postępowania administracyjnego sktadam skarge na pracownika supermarketu ,Tesco”). Na element ten należy więc zwracać większą uwagę w procesie nauczania, gdyż w prawdziwym życiu może on istotnie wpłynąć na rozpatrzenie skargi.

W zasadniczej treści pisma nadawca opisuje przedmiot skargi, określa swój stan emocjonalny, komentuje, dokonuje oceny sytuacji i projektuje stan pożądany. Przedmiot skargi powinien być jasno i precyzyjnie określony, nadawca musi więc: wskazać obiekt skargi (winnego przewinienia), nazwać przewinienie oraz przedstawić okoliczności zdarzenia (Wyrwas 2002, s. 95). Obiektem skargi ,jest osoba lub instytucja, która postępuje niezgodnie z obowiązującymi normami (w tym prawnymi), naruszając przy tym słuszny interes innej osoby" (Wyrwas 2002, s. 95).

Obiektem skarg pisanych przez studentów był/-a (zgodnie z poleceniem) sprzedawca/sprzedawczyni w sklepie. Winny wskazany został przez wszystkich nadawców, a w większości przypadków ogólnie określano jego stanowisko pracy, np. (1) Pragne złożyć skargę na pracująca w Państwa sklepie ekspedientke; (2) chciałabym złożyć skargę na sprzedawczyni sklepu „Biedronka”.

Skuteczność skargi w dużej mierze zależy od precyzji podawanych informacji, dlatego, jak zauważa Wyrwas, nadawcy często podają „(...) imiona, nazwiska, czasem także opisują wygląd nieznanej z nazwiska osoby lub informują o okolicznościach zdarzeń, jeżeli te fakty mogą być pomocne w zidentyfikowaniu obiektu skargi" (2002, s. 96). Z przeprowadzonych analiz wynika, że studenci raczej nie starali się precyzyjnie i jednoznacznie wskazać osoby, na którą pisali skargę, co 
być może wynikało z symulacyjnego charakteru zadania. W materiale zebranym w pierwszym etapie dane personalne podało $29,03 \%$ studentów, a w etapie drugim o 1,95\% mniej (27,08\%). Najczęściej podawaną informacją pozwalającą na lepszą identyfikację winnego była data, a niekiedy także godzina zdarzenia, np.: (1) Składam skarge na sprzedawcę sklepu „Stokrotka”, który w dniu 05 czerwca 2012 r. obstugiwał klientów; (2) (...) oświadczam iż dnia 15 maja 2012 roku około godziny 11.00 zostałem publicznie obrażony przez pana Jana X.

Przewinienie zostało wskazane we wszystkich przeanalizowanych pracach. W większości przypadków studenci ogólnie określali przyczynę pisania skargi, np.: (1) Informuję o tym, że sprzedawca nie jest kompetentny, nie rozumie sie $w$ ogóle o co chodzi klientom. Jest niegrzeczny. W ogóle nie wie, co poradzić; (2) (...) pragnę złożyć skargę na personel sklepu. Wszyscy sa bardzo nie życzliwi i bardzo leniwi.

Niektórzy bardziej szczegółowo opisywali zachowanie sprzedawcy, precyzując, w jaki dokładnie sposób zostali obrażeni czy też skrzywdzeni, np.:

- Obrażał mnie i oszukał mnie kiedy wydałał reszte. Kiedy powiedziałem mu że się pomylił, uderzył mnie w twarz.

- Rzucał we mnie pudłem z gazetami i przez to musiałam przejść rehabilitacje w klinice.

- Kiedy już stojałam przy kasie wywalił mi wszystkie zakupy z torebki, za to że chciałam płacić nie gotuwką, a kartą.

Dość często studenci wspominali, że sprzedawca używał wobec nich przekleństw $(8,06 \% \text { i } 25 \% \text { tekstów })^{11}$, przy czym niekiedy nie znając odpowiedniego leksemu, używali określeń typu brzydkie / złe słowa, co brzmi nieco infantylnie i w tekście oficjalnego pisma wywołuje efekt komizmu, np.: (1) wyzywat mnie od najgorszych na oczach innych konsumentów, używając przy tym między innymi stów na $k$, p oraz s; (2) zaczęła mówić złe stowa; (3) wykrzykiwat niegrzeczne stowa; (4) zacząt przeklinać, i mówić do mnie brzydkie słowa.

Podane tu przykłady określania przewinienia pochodzą z drugiej części badania, dla porównania warto także przyjrzeć się cytatom z etapu pierwszego, gdyż zestawienie takie pozwala ukazać różnice w poziomie kompetencji językowych oraz wynikającej z nich precyzji przekazywania informacji.

- Pan Andrzej Grzyb arogantnie przemówił do mnie, poniżając moją godność.

- Pani sprzedawczyni oskarżyła moją cześć, powiedzą do mnie dużo różnych brudnych słów.

- Pani spszedawczynia żle ze mną romowiała.

- Chciałabym poinformować, że obsługa była okrutna.

- powiedział do mnie brzydkie, nieprzystojne słówko na literu "k"

${ }^{11}$ Taki zapis wyników procentowych oznacza wartości odpowiednio dla pierwszego i drugiego etapu badania. 
Ważnym elementem skargi są okoliczności zdarzenia, które dostarczają odbiorcy szerszej wiedzy o zaistniałej sytuacji i pozwalają na podjęcie stosownej decyzji. „Dokładna relacja ma kreować u odbiorcy pozytywny wizerunek skarżącego, a odwoływanie się do faktów ma ukazywać go jako osobę uczciwą i godną zaufania, a więc w pełni zasługującą na "pozytywne rozpatrzenie sprawy «" (Wyrwas 2002, s. 101). Dobrze opisane zdarzenie, niepozostawiające żadnych wątpliwości i świadczące na korzyść nadawcy pozytywnie wpływa na moc illokucyjną skargi. Studenci, szczególnie w drugim etapie badania, zdawali sobie sprawę z potrzeby przekonania odbiorcy do swojej racji, dlatego często starali się dokładnie opisać przebieg wydarzeń, np.:

Z początku kiedy przyszłam do sklepu nikt na mnie nie zwrócił uwagi. Podrugie, kiedy poprosiłam, żeby sprzedawca mi pomógł, on bez chęci poszedł za mną, a kiedy u niego zadzwonił telefon komurkowy, on wogule zapomiętał o mnie. Dalej-więcej. Już sama poszłam do przymierzalnie i wszystko wymierzyłam. $\mathrm{Z}$ dwoma rzeczami podeszłam do kasy z nadzieją, że sprzedawca już źmienił się. Moje nadzieje nie spełniłyście. Przedemną stojał ten samy sprzedawca. Rozmawiał ze mną bardzo źle i nieprzyjemno.

W badanym materiale, szczególnie w pierwszym etapie, często pojawiały się prace zawierające zbyt drobiazgowe opisy przebiegu zdarzenia oraz zbędne informacje m.in. na temat zakupionych produktów oraz ich cen, np.: Kupiłam mleko, szynkę, jogurt owocowy, pót kilo ziemniaków, ketchup łagodny i sok pomarańczowy. Piszący chętnie opisywali swoje myśli i przeżycia wewnętrzne, starali się budować napięcie i ubarwiać przedstawianą sytuację, dlatego też niektórym skargom bliżej było do opowiadania niż do tekstu urzędowego. Oto jeden z bardziej emocjonujących przykładów z pierwszego etapu badania:

To odbyło się 30 lutego 1995 roku. Była noc, przyszedłem do sklepu, nikogo nie było, ten sprzedawca patrzył na mnie, zauważył mój lęk. Poszedłem szukać chleb. Kiedy doszedłem, zauważyłem cień przed sobą. To był sprzedawca. Powiedział, że sklep już musze być zamknięty. Powiedziałem, że tylko weźmię chleb i wyjdę. Poszliśmy do kasy. On powiedział, że ja muszę zapłacić tylko dwa złotych. Oddałem mu pięćset złotych. Sprzedawca usmiechnuł się i oddał mnie reszty 188 zł. Od razu zauważyłem jego oczy. Były ognie. Patrzył na mnie jak wilk, trzymając resztę. Wybiegłem stąd. Dzisiaj jest 2011 rok. Znalazłem paragon i chciałbym wrócić swoje pieniądze do siebie.

Wydawnictwa poprawnościowe przestrzegają przed koncentrowaniem się na opisie swojego stanu emocjonalnego oraz poczuciu krzywdy i pouczają, że „Jeśli taki fragment się pojawia, to swoje oburzenie należy wyrazić tak, aby nie obrazić adresata i nie grozić mu. W formie informacji można napisać na przykład: $W$ razie braku interwencji będziemy zmuszeni do zwrócenia się do instytucji nadrzędnej (Zaśko-Zielińska i in. 2006, s. 765). Przeprowadzone analizy wskazują na 
znaczną różnicę w podejściu do opisywania stanu emocjonalnego w pierwszym i drugim etapie badania. Studenci o wiele chętniej mówili o swoich przeżyciach tuż po przyjeździe do Polski, natomiast teksty pisane po roku nauki były bardziej stonowane, konkretne i skupione na faktach. Badani wyrażali swoje emocje m.in. poprzez odpowiednio dobraną leksykę nazywającą uczucia, np.: (1) Byłam tak wściekła, że nie mogłam spokojnie mu wyjaśnić wszystko i nakryczałam; (2) Poczułam się skrzywdzona.

W pierwszym etapie badania niemal dwukrotnie częściej (11,29\% i 6,25\%) na określenie zachowania sprzedawcy używano potocznego leksemu „cham” oraz pochodzących od niego przymiotnika i przysłówka, np.: (1) To niemożliwe, żeby taki cham pracowat z klientem; (2) Jestem przerażona takim chamskim zachowaniem sprzedawcy; (3) sprzedawca potraktowat mnie po chamsku.

Silne wzburzenie manifestowano także za pomocą wykrzykników. W pierwszym etapie badania znak ten pojawił się w $14,52 \%$ tekstów, w drugim już tylko w $4,17 \%$, np.:

- To jest koszmarne! Jestem bardzo rozczarowany! Nigdy już nie przyjdę do tego sklepy jeśli państwo nie ukarają sprzedawcę! Przecierz może jeszcze okłamać jeszcze dużo ludzi!

- (...) byłam bardzo przerożona kiedy zobaczyłam, że sprzedawca nagimi brudnymi rękami brał mięso i łożył go do reklamówki! To jest nemożliwe!

W analizowanych tekstach pojawiały się także liczne odwołania do emocji pozytywnych, przy czym zabiegi te miały dwa różne cele. Pierwszym z nich było stworzenie kontrastu, pozwalającego na podkreślenie rozmiaru doznanej krzywdy - piszący opisywali swój doskonały nastrój przed niemiłym wydarzeniem w sklepie, np.: (1) Dzisiaj przyszedtam do waszego sklepu mając bardzo dobry nastrój; (2) Dziszaj dla mni byt ładny dzieni. Bytam szczęśliwa, miałam nastrui, i poiechatam na zakupy. Drugą przyczyną odwoływania się do emocji pozytywnych była chęć zjednania sobie sympatii odbiorcy. Studenci wspominali w swoich skargach (16,13\% i 12,50\% prac), że są stałymi klientami sklepu i zapewniali, że dotychczas zawsze byli zadowoleni z obsługi, np.:

- Chodzę co weekend do Pana sklepu. Kupuję bardzo dużo rzeczy (...) Jestem zawsze zadowolony z Pana sklepów i bardzo cieszę się że są takie sklepy w naszej miejscowości.

- Szanowny Panie Kierowniku, zawsze podobało mi się robić zakupy w Pana sklepie, ponieważ jest bogaty asortyment, częste promocje i dobra obsługa.

Co ciekawe, w materiale z pierwszego etapu badania odnotowano $17,74 \%$ tekstów, w których nadawcy usprawiedliwiali przed odbiorcą swoją decyzję o złożeniu skargi. Zapewniali, że sytuacja ta jest dla nich bardzo nieprzyjemna, jednak robią to w imię sprawiedliwości, dla dobra innych ludzi, a nawet dla dobra sklepu. Oto kilka fragmentów: 
- Bardzo mi przykro, ale muszę napisać do państwa skargę dotyczącą sprzedawca NN.

- $\quad$ Nie bardzo mi miło to pisać, ale każdy musi odpowiadać za swoje zachowanie.

- Nie lubie konfliktów, ale zachowanie pracownika Pańskiego sklepa było niesamowite.

Zdania tego typu często pojawiały się już w formule inicjalnej. Można przypuszczać, że ich występowanie związane jest $\mathrm{z}$ brakiem wiary w możliwość obrony swoich praw wyniesionej z doświadczeń z kraju pochodzenia. W byłych republikach radzieckich prawa konsumenta ciągle nie są jeszcze wystarczająco chronione, a dodatkowo istnieją nieformalne hierarchie społeczne, w których na szczycie znajdują się osoby, od których coś zależy, nieważne czy jest to dyrektor dużej fabryki czy portierka wydająca klucze. Traktowanie innych z góry jest na porządku dziennym i ludzie raczej rzadko piszą z tego powodu skargi ${ }^{12}$. Dlatego właśnie niektórzy studenci dość nieśmiało podchodzili do wyrażania oburzenia i starali się złagodzić efekt swojego działania. Zdarzały się nawet próby usprawiedliwiania złego zachowania sprzedawcy, a także prośby o łagodne potraktowanie go, np.: Pani sprzedawczyni była młoda, może kilku dni pracuje w Pańskim sklepu, tak sobie pomyślałam. Proszę Pana, żeby porozmawiat z nia. Nie wiem, co jeszcze można zrobić, ale to bez żadnej uwagi zostawiać nie trzeba. W drugim etapie badania wypowiedzi takie nie zdarzały się w ogóle, a studenci w o wiele pewniejszy sposób wyrażali swoje wzburzenie i stawiali żądania.

Formula finalna składa się z obowiązkowego petitum oraz fakultatywnie z podziękowań i apelu, zawierającego prośbę o rozpatrzenie i/lub pozytywną odpowiedź. Petitum decyduje o skuteczności skargi i zawiera prośbę (czy też żądanie) o interwencję, wymierzenie kary, zadośćuczynienie. Ten konstytutywny element tekstu zamieścili niemal wszyscy studenci, zabrakło go zaledwie w 3 pracach $(4,83 \%)$ pisanych na pierwszym etapie badania. Co istotne, żądania stawiane po rocznym kursie języka polskiego były konkretniejsze i o wiele częściej wyrażane wprost. Niektórzy studenci bardzo ogólnie prosili o zajęcie się sprawą, interwencję, wyciągnięcie konsekwencji nie precyzując, czego dokładnie oczekują, np.: (1) Chciatbym, żeby Pan zwrócił na to uwage, ponieważ takie zachowanie jest niedopuszczalne; (2) Mam nadzieję, że poniesie jakiekolwiek konsekwencję. Inni stawiali konkretne żądania, domagając się ukarania osoby skarżonej, niejednokrotnie poprzez wyrzucenie jej z pracy i nałożenie kary finansowej, np.: (1) Proszę zwolnić sprzedawcę i nałożyć na niego kare pieniężną; (2) Prosze wywalić go s pracy. Pojawiały się także żądania zadośćuczynienia w postaci przeprosin, zwrotu pieniędzy czy też wypłaty odszkodowania, np.:

- Chciałabym oskarżyć pracownika o nieprawdłowym chamskim zachowaniu oraz dostać kompensację moralną od pracownika w formie wybaczenia.

${ }^{12}$ Ciekawe mogłoby być porównanie treści skarg pisanych przez studentów ze Wschodu i Zachodu. 
- Wymagam odszkodowania za poniesione straty moralne i finansowe.

- Proszę o niezwłoczne zwolnienie powyżej wymienionego sprzedawcy za złe traktowanie i obsługiwanie klientów, a także kompensację moralną w rozmiarze $200 \mathrm{zł}$.

Cytowane tu żądania pochodzą z materiału zebranego w drugim etapie badania. Dla porównania warto zacytować kilka fragmentów z tekstów pisanych tuż po przyjeździe do Polski. Studenci wiedzieli wprawdzie o potrzebnie zamieszczenia tego elementu, jednak brak znajomości konwencji i utartych formuł oraz niski poziom kompetencji językowych powodowały, że ich moc illokucyjna była o wiele słabsza:

- Nie chcę ani z panem, ani z pracodawkę kłucić się, bo mam dobre serce. Jedynie o co proszę, żeby ta kobieta poprosiła przebaczenia u mnie u miło się uśmiechnęła.

- Proszę o mandacie temu sprzedawcy.

- Proszę zwolnić go z pracy i będę podac skargę do sęda.

- Mam nadzieję, że Pan adekwatnie popatrzy na moją skargę, zrobi prawidłowy wniosek i Pan wyda mi odszkodowanie, albo uwolni tą zwariowaną sprzedawczynię.

- Dlatego chcę, żeby sklep „Milea”, za to, że pracownik sklepu mnie obraził, wypłacił mnie sumu pieniądzy. Ile, niech zastanowi Pan Dyrektor.

\subsection{DODATKOWE INFORMACJE}

W końcowej części skargi nadawcy zamieszczają niekiedy informacje na temat ewentualnych świadków zdarzenia oraz załączników stanowiących dowód na prawdziwość relacji. Elementy te bardzo rzadko pojawiały się w badanym materiale i występowały nie tylko na końcu, ale również w treści zasadniczej skargi, np.:

- Pan sprzedawca rzucał we mnie nożem i krzyczał precz z mojego sklepu. Jako dowód wysyłam zakrwawioną koszulkę.

- Jako dowód mam Swiadków i nagranie na wideo w sklepie.

- Dołączam do skargi nagranie z głosem sprzedawcy, który klnie na mnie.

\section{WNIOSKI}

Program nauczania języka polskiego jako obcego powinien być dostosowany zarówno do poziomu, jak i potrzeb uczących się. Skarga jako gatunek tekstu służący komunikacji obywatela z różnego typu instytucjami jest szczególnie istotna 
dla osób, które planują przynajmniej na jakiś czas zamieszkać w Polsce. Zajęcia z pisania skargi pozwalają na przygotowanie uczących się do pełnienia różnych ról społecznych, $w$ tym roli obywatela, petenta i konsumenta. $Z$ jednej strony służą więc kształceniu kompetencji komunikacyjnych, z drugiej zaś pozwalają na przekazywanie wiedzy praktycznej.

Z przeprowadzonych analiz wynika, że po roku nauki nastąpił znaczny wzrost zarówno w zakresie kompetencji językowych, jak i genologicznych uczących się. W drugim etapie badania piszący wykazali się nie tylko lepszą znajomością struktury wypowiedzi, ale stosowali również specjalistyczną leksykę i składnię charakterystyczną dla gatunku. Wyniki analizy materiału z drugiego etapu badania wskazują także na miejsca, na które należy zwrócić szczególną uwagę w procesie nauczania, gdyż po roku nauki nadal nie zostały one w pełni przyswojone.

\section{BIBLIOGRAFIA}

Bachtin M., 1986, Estetyka twórczości słownej, Warszawa.

Busiło S., 2017, Cudzoziemiec w urzędzie. Elementy języka prawa i administracji publicznej w programach nauczania języka polskiego jako obcego, „Acta Universitatis Lodziensis. Kształcenie Polonistyczne Cudzoziemców”, t. 24, G. Zarzycka, M. Karasek (red.), s. 45-60. https://doi. org/10.18778/0860-6587.24.04

Dunin-Dudkowska A., 2016, Gatunki urzędowo-prawne w perspektywie glottodydaktycznej, w: W. Próchniak, M. Smoleń-Wawrzusiszyn (red.), Nauczanie języka polskiego jako obcego. Tradycje i innowacje, Lublin, s. 65-77.

Dunin-Dudkowska A., 2018, Gatunki wypowiedzi w kontekście glottodydaktycznym, „Acta Universitatis Lodziensis. Kształcenie Polonistyczne Cudzoziemców”, t. 25, B. Grochala, I. Dembowska-Wosik (red.), s. 111-122. https://doi.org/10.18778/0860-6587.25.10

Dunin-Dudkowska A., 2019, The cover letter as a genre of speech in teaching Polish as a foreign language, „Acta Universitatis Lodziensis. Kształcenie Polonistyczne Cudzoziemców”, t. 26, G. Zarzycka, B. Grochala, I. Dembowska-Wosik (red.), s. 221-229. https://doi. org/10.18778/0860-6587.26.16

ESOKJ - Europejski system opisu ksztatcenia językowego: uczenie się, nauczanie, ocenianie, 2003, Warszawa.

Gajda S., 2001, Gatunek jako konwencja kulturowo-językowa, w: J. Bartmiński (red.), Współczesny język polski, Lublin, s. 255-268.

Grochala B., 2019, O ksztaltowaniu kompetencji genologicznej w nauczaniu języka polskiego jako obcego, „Acta Universitatis Lodziensis. Kształcenie Polonistyczne Cudzoziemców”, t. 26, G. Zarzycka, B. Grochala, I. Dembowska-Wosik, (red.), s. 221-229. https://doi. org/10.18778/0860-6587.26.15

Janowska I. i in. (red.), 2016, Programy nauczania języka polskiego jako obcego. Poziomy A1-C2, Kraków.

Kwiatkowska K., 2011, Miejsce życiorysu w nauczaniu języka polskiego jako obcego, w: K. Pluskota, K. Taczyńska (red.), Nowe perspektywy w nauczaniu języka polskiego jako obcego II, Toruń, s. 266-280.

Kwiatkowska K., 2012, „Zgłaszam się do Was w pytaniu o...”, czyli o tym, jak Polacy ze Wschodu realizuja wybrane aspekty wzorca gatunkowego podania, „Język a Kultura”, t. 23, A. Burzyńska-Kamieniecka (red.), s. 257-272. 
Makarewicz H., 2007, Pisanie po rosyjsku. Zasady, wzory, ćwiczenia, Warszawa

Malinowska E., 2001, Wypowiedzi administracyjne. Struktura i pragmatyka, Opole.

Rozporządzenie Ministra Nauki i Szkolnictwa Wyższego z dnia 26 lutego 2016 r. w sprawie egzaminów z języka polskiego jako obcego.

Ruszer A., 2010, Oswoić tekst. Podręcznik kompozycji i redakcji tekstów użytkowych dla poziomów B2 $i$ C1, Kraków.

Ustawa z dnia 14 czerwca 1960 r. Kodeks postępowania administracyjnego, Dz.U. $1960 \mathrm{nr} 30$ poz. $168 \mathrm{z}$ późn. zm.

Wojtak M., Wprowadzenie do genologii, Lublin 2019.

Wyrwas K., 2000, Wzorzec gatunkowy skargi i jego realizacje (na przykładzie tekstów literackich oraz skarg do instytucji), w: D. Ostaszewska (red.), Gatunki mowy i ich ewolucja, t. 1: Mowy piękno wielorakie, Katowice, s. 119-135.

Wyrwas K., 2002, Skarga jako gatunek mowy, Katowice.

Zaśko-Zielińska M., Majewska-Tworek A., Piekot T., 2006, Wzory tekstów użytkowych, w: M. Bańko (red.), Polszczyzna na co dzień, Warszawa, s. 659-800.

Kamila Kwiatkowska

\section{GENRE PATTERN OF A COMPLAINT LETTER IN TEACHING POLISH AS A FOREIGN LANGUAGE}

Keywords: teaching Polish as a foreign language, genre competence, genre pattern of complaint letter

Abstract. The purpose of the article is to present results of an analysis of how students of Polish as a foreign language implement the genre pattern of a complaint letter. The study group included Slavic students of the Centre of Polish and Polish Culture for Polish People from Abroad and Foreigners UMCS in Lublin. The research was conducted twice - at the beginning and in the end of the academic year. Therefore it's results show the increase of learners communication competences and the elements that should be given special attention in the teaching process. The article also stresses that teachers of Polish as a foreign language should pay more attention to achievements of genre studies. It also presents a description of the genre pattern of a complaint letter. 